\title{
Detection of circulating antigen in amoebic liver abscess by counter-current immunoelectrophoresis
}

\author{
S. C. PARIJA and B. M. S. KARKI \\ Department of Microbiology, Jawaharlal Institute of Postgraduate Medical Education and Research, \\ Pondicherry 605006, India
}

Fifty serum samples from patients with amoebic liver abscess and 50 from subjects who had not suffered from the disease (25 from patients with other, chiefly parasitic, infections and 25 from healthy blood donors, staff or students) were tested for circulating amoebic antigen by counter-current immuno-electrophoresis (CIEP). Amoebic antigen was detected in 38 sera (76\%) from cases of amoebic liver abscess, but in none of the other sera. Although CIEP is only moderately sensitive, the high specificity suggests that this simple test may be useful in the diagnosis of amoebic liver abscess.

\section{Introduction}

Clinical manifestations of amoebic liver abscess are variable, and diagnosis depends upon radiography, ultrasonography, computed tomography, magnetic resonance imaging and serodiagnostic methods [1].

Serodiagnosis is based mainly on the demonstration of circulating amoebic antibodies [2]. Although antibodybased serological tests are specific, false negative results commonly occur and these tests do not discriminate between active and past infection, as amoebic antibody titres persist for months or years even after treatment. Serological tests for the detection of circulating amoebic antigens provide a better way of discriminating between current or recent and past infection, as the presence of antigen in serum indicates an active infection [3].

The objective of the present study was to evaluate counter-current immuno-electrophoresis (CIEP) for the detection of amoebic antigen in serum for the diagnosis of amoebic liver abscess. CIEP has been used for the detection of specific antigens in various diseases [4-7], including hydatid disease $[8,9]$. Although the test has been used for the detection of antibodies in serum and amoebic antigen in the liver pus of patients with amoebic liver abscess [6], to the

Received 30 Sept. 1997; revised version received 28 April 1998; accepted 29 April 1998.

Corresponding author: Professor S. C. Parija. E-mail: jipmer@jipmer.ren.nic.in best of our knowledge there is no report of the use of CIEP for the detection of circulating amoebic antigen in serum.

\section{Materials and methods}

\section{Serum}

A total of 100 serum samples was collected from patients and control subjects attending the Jawaharlal Institute of Postgraduate Medical Education and Research Hospital, Pondicherry, India. Fifty of these sera were from patients with amoebic liver abscess, selected on the basis of three or more criteria modified from those recommended by Chuttani et al. [10], and described in an earlier study [11], as follows: (a) needle aspiration from an enlarged and tender liver of bacteriologically sterile 'anchovy sauce' pus, with or without demonstration of Entamoeba histolytica trophozoites by direct microscopy, or culture, or both; (b) radiological evidence (raised and fixed right cupola of the diaphragm) and ultrasonography findings indicative of an abscess (no significant wall echoes; round or oval shape; less echogenicity than normal liver parenchyma, with fine homogeneous low level echoes throughout at high grain with particulate motion and a location contiguous to the liver capsule and distal sonic enhancement) [12]; (c) amoebic serum antibody titre $\geqslant 128$; (d) positive response to anti-amoebic therapy.

Sera were also collected from 10 cases of hydatid disease, 10 cases of filariasis, three cases of hookworm infection, two cases of lower respiratory tract infection and 25 apparently healthy subjects (staff, students and 
blood donors) who had not suffered from any symptoms of amoebiasis in the previous 6 months.

All sera were inactivated at $56^{\circ} \mathrm{C}$ for $30 \mathrm{~min}$, preserved with sodium azide $0.015 \mathrm{~mol} / \mathrm{L}$ and stored at $-20^{\circ} \mathrm{C}$ until used.

\section{Antigen}

A sonicated extract of axenically grown E. histolytica (NIH: 200) prepared by the method described by Sawhney et al. [13] was used. Briefly, amoebae from a 48-h culture were washed three times in sterile physiological saline, concentrated by centrifugation at $500 \mathrm{~g}$ for $30 \mathrm{~min}$ and sonicated in the cold for $5 \mathrm{~min}$ in an ultrasonic disintegrator (MSE Scientific Instruments) with 1-min bursts and 2-min breaks between bursts. The sonicate was centrifuged at $10000 \mathrm{~g}$ for $30 \mathrm{~min}$ and the supernate was used as axenic amoebic antigen.

\section{Hyperimmune antiserum}

Axenic amoebic antigen was emulsified with an equal volume of Freund's complete adjuvant. Adult rabbits $(3-4 \mathrm{~kg})$ were given $0.5 \mathrm{ml}$ of this emulsion by intramuscular injection in all four limbs. Injection was repeated after 6 weeks, and 10 days later serum was collected and tested for antibodies to amoebic antigen by indirect haemagglutination assay (IHA) [14]. The amoebic antibody titre of the serum was 1024.

\section{CIEP}

Gels prepared on $50 \times 75 \mathrm{~mm}$ glass slides with Difco Bacto agar $1 \%$ in veronal buffer $(\mathrm{pH} 8.4)$, were allowed to set at room temperature and stored at $4{ }^{\circ} \mathrm{C}$ overnight. Six pairs of wells, $4 \mathrm{~mm}$ in diameter and $3 \mathrm{~mm}$ apart, were punched out on the slides with a template. Each well was filled with $10 \mu \mathrm{l}$ of the appropriate reactant. Wells containing hyperimmune antiserum (titre 1024) were placed on the anodic side of the electrophoretic chamber and patients' sera on the cathodic side. The chambers were filled with veronal buffer $(0.05 \mathrm{M}, \mathrm{pH}$ 8.4) and a current of $8 \mathrm{~V} / \mathrm{cm}$ was applied for $30 \mathrm{~min}$. Immediately after completion of electrophoresis the slides were read unstained with oblique lighting against a black background. The slides were then stained and re-read.

Unprecipitated protein was washed out of the agar by immersion of the slide for $24 \mathrm{~h}$ in veronal buffer. The slide was then washed for $15 \mathrm{~min}$ in acetic acid $1 \%$ to remove excess salt. Staining was with a solution of amidoblack $1 \%$ made in a solvent containing glacial acetic acid $1 \mathrm{ml}$, distilled water $49 \mathrm{ml}$ and methylated spirit $50 \mathrm{ml}$ for $30 \mathrm{~min}$. Excess stain was washed with the solvent to give a preparation with dark bluish precipitation bands on a clear background. The slide was finally soaked in acetic acid $1 \%$ containing glycerol $1 \%$ for $15 \mathrm{~min}$ and dried at $37^{\circ} \mathrm{C}$ in an incubator. Positive reactions were defined by lines of precipitation between antigen and hyperimmune serum. Positive and negative controls were included in each test.

\section{IHA}

Circulating antibodies in serum were measured by IHA as described by Parija et al. [14]. An antibody titre of $\geqslant 128$ was considered to be diagnostic of amoebiasis.

\section{Analysis of data}

Data were analysed with the Epi-info package (World Health Organization). Sensitivity and specificity of the assays were calculated by the method of Park [15].

\section{Results and discussion}

The results are summarised in Table 1, which shows the comparative sensitivity and specificity of CIEP and IHA for the detection of serum antigen and antibodies, respectively, in the diagnosis of amoebic liver abscess. Serum specimens collected from healthy controls and from patients with other parasitic and infective conditions were uniformly negative when tested by CIEP and mostly negative by IHA. The positive and negative predictive values of CIEP were $95.7 \%$ and $90.5 \%$, respectively; those of IHA were $93.1 \%$ and $83.9 \%$, respectively.

The observed sensitivity of CIEP (76\%) compares well with that of an enzyme-linked immunosorbent assay (ELISA) (93\%) for the detection of antigen in sera of patients with amoebic liver abscess [16], but is lower than the $100 \%$ sensitivity of solid phase radioimmunoassay reported by Pillai et al. [17]. In the present study, 41 sera $(82 \%)$ from cases of amoebic liver abscess were positive for amoebic antibodies by IHA. CIEP detected antigen in sera of 9 cases $(18 \%)$ which were negative for circulating antibodies by IHA. Conversely, CIEP failed to detect 12 cases (24\%) of amoebic liver abscess which were positive by IHA. The failure of CIEP to detect antigen in these cases may be due to the formation of immune complexes of amoebic antigen and antibodies, leading to the absence of free amoebic antigen in the serum.

Table 1. Evaluation of CIEP and IHA in the diagnosis of amoebic liver abscess

\begin{tabular}{lcc}
\hline Subject groups & $\begin{array}{c}\text { Number (\%) } \\
\text { positive by } \\
\text { CIEP }\end{array}$ & $\begin{array}{c}\text { Number (\%) } \\
\text { positive by } \\
\text { IHA }\end{array}$ \\
\hline Amoebic liver abscess $(\mathrm{n}=50)$ & $38(76)$ & $41(82)$ \\
Infected controls $*(\mathrm{n}=25)$ & 0 & $3(12)$ \\
Healthy controls $(\mathrm{n}=25)$ & 0 & 0 \\
\hline
\end{tabular}

* Hydatid disease (10); filariasis (10); hookworm infection (3); lower respiratory tract infection (2) 
Alternatively, the volume of free antigen may be too low to be detected by CIEP, which is only moderately sensitive.

CIEP has been widely used for the detection of antigen in serum, or other body fluids in the diagnosis of various parasitic and other infections [4-9]. It has also been used previously for the detection of amoebic antibodies in serum in the diagnosis of amoebic liver abscess, but not for the detection of circulating amoebic antigen.

ELISA [16] and solid phase radio-immunoassay [17] have been used to detect circulating amoebic antigen in the diagnosis of amoebiasis. These tests, although sensitive, are expensive and require technical expertise and thermolabile reagents. They are difficult to adopt in poorly equipped laboratories and there is need for a simple and economical, yet reliable test which permits the spot diagnosis of amoebic liver abscess in the field and rural health centres with inadequate laboratory facilities. CIEP, which requires simple instrumentation and inexpensive reagents, fits these criteria well.

We thank Dr V. K. Vinayak, Department of Experimental Medicine, Postgraduate Institute of Medical Education and Research, Chandigarh for supplying axenic antigen of E. histolytica for the study.

\section{References}

1. Parija SC. A text book of medical parasitology. Colour atlas and text. Madras, AIPD. 1996.

2. Parija SC. Laboratory diagnosis of amoebiasis. Antiseptic 1992; 88: $506-510$.

3. Parija SC. Recent trends in the diagnosis of amoebiasis. $J$ Assoc Physicians India 1993; 41: 383-385.
4. Greenwood BM, Whittle HC, Dominic-Rajkovic O. Countercurrent immunoelectrophoresis in the diagnosis of meningococcal infections. Lancet 1971; ii: $519-521$.

5. Prince AM, Burke KC. Serum hepatitis antigen $(\mathrm{SH})$ : rapid detection by high voltage immunoelectroosmophoresis. Science 1970; 169: 593-595.

6. Mahajan RC, Ganguly NK. Amoebic antigen in immunodiagnosis and prognosis of amoebic liver abscess. Trans $R$ Soc Trop Med Hyg 1980; 74: 300-302.

7. Remington JS, Gaines JD, Gilmer MA. Demonstration of Candida precipitins in human sera by counterimmunoelectrophoresis. Lancet 1972; 1: 413

8. Shariff GM, Parija SC. Counter-current immunoelectrophoresis test for serodiagnosis of hydatid disease by detection of circulating hydatid antigen. J Microbiol Methods 1991; 14: 71-76.

9. Parija SC, Ravinder PT, Subba Rao KSVK. Detection of hydatid antigen in urine by countercurrent immunoelectrophoresis. J Clin Microbiol 1997; 35: 1571-1574.

10. Chuttani PN, Pathania NS, Sharma TD. Amoebic abscess of liver. An analysis of 135 cases. J Indian Med Assoc 1963; 40: 489-493.

11. Karki BMS, Parija SC. Co-agglutination test for the detection of circulating antigen in amoebic liver abscess. Am J Trop Med Hyg 1998 (in press).

12. Ralls PW, Barnes PF, Radin DR, Colletti P, Halls J. Sonographic features of amebic and pyogenic liver abscesses: a blinded comparison. Am J Roentgenol 1987; 149: 499-501.

13. Sawhney $\mathrm{S}$, Chakravarti RN, Jain P, Vinayak VK. Immunogenicity of axenic Entamoeba histolytica antigen and its fractions. Trans $R$ Soc Trop Med Hyg 1980; 74: 26-35.

14. Parija SC, Kasinathan S, Rao RS. Long shelf-life of antigensensitised erythrocytes by double aldehyde stabilisation for the serodiagnosis of amoebiasis by indirect haemagglutination. J Diarrhoeal Dis Res 1988; 6: 29-34.

15. Park JE. Text book of preventive and social medicine. Jabalpur, Banarasidas Bhanot. 1994.

16. Vinayak VK, Shandil RK, Bansal V, Singh K, Bhasin DK, Kaur U. Uses and limitations in the demonstration of specific circulating immune complexes in patients with amoebiasis. $J$ Med Microbiol 1990; 32: 87-91.

17. Pillai S, Mohimen A. A solid-phase sandwich radioimmunoassay for Entamoeba histolytica proteins and the detection of circulating antigens in amoebiasis. Gastroenterology 1982; 83: $1210-1215$. 